\title{
Parrot populations and habitat use in and around two lowland Atlantic forest reserves, Brazil
}

\author{
Stuart J. Marsden ${ }^{\mathrm{a}, *}$, Mark Whiffin ${ }^{\mathrm{a}}$, Lisa Sadgrove ${ }^{\mathrm{a}}$, Paulo Guimarães Jr ${ }^{\mathrm{b}}$ \\ ${ }^{a}$ Behavioural and Environmental Biology Group, Department of Biological Sciences, The Manchester Metropolitan University, Chester Street, \\ Manchester M1 5GD, UK \\ ${ }^{\mathrm{b}}$ Plant Phenology and Seed Dispersal Research Group, Departamento de Ecologia, Universidade Estudual Paulista (UNESP), CP 199, \\ 13506-900 Rio Claro, SP, Brazil
}

Received 13 November 1999; received in revised form 4 April 2000; accepted 7 April 2000

\begin{abstract}
We estimated population sizes of parrots in a large (Sooretama/Linhares) and a small (Porto Seguro) lowland Atlantic forest reserve, and examined their habitat associations within the reserves, and their use of forest fragments. In Sooretama, most species had estimated populations between 1000 and 20,000 individuals, but in the smaller reserve population densities were low and all but one species had population estimates $<500$. Two Amazons, including the 'Endangered' Amazona rhodocorytha, were strongly linked to primary forests whereas the 'Vulnerable' Pyrrhura cruentata was associated with non-pristine forest. There was considerable movement of parrots between the Sooretama reserve and the surrounding country with Amazona species tending to fly into the reserve during the mornings, and the macaw Propyrrhura maracana flying out. Other species, notably P. cruentata and P. leucotis, were never recorded away from the reserve. Most parrot populations in the region are likely to be small, and the substantial populations around Sooretama make this reserve a parrot stronghold. It is crucial that fire, illegal logging and parrot capture are adequately controlled within Sooretama, and there is a strong argument for extending conservation management efforts to areas immediately outside the reserve. (C) 2000 Elsevier Science Ltd. All rights reserved.
\end{abstract}

Keywords: Parrots; Atlantic Forest; Population sizes; Amazona; Pyrrhura.

\section{Introduction}

The Atlantic Forest once covered around 1 million $\mathrm{km}^{2}$ in the now heavily populated eastern part of Brazil (Fonseca, 1985). Less than 10\% of the forest remains in most states, with deforestation being particularly heavy in some of the coastal lowlands (Fonseca, 1985; Viana et al., 1997). Much of what is left of the forest is highly fragmented, and little is officially protected (Viana et al., 1997; Ranta et al., 1998). Areas outside forest reserves are dominated by sugar cane, pasture, coffee and Eucalyptus plantations.

The region holds around 200 endemic bird species, many of which are believed to be threatened, primarily due to habitat alteration (Sick, 1993; Collar et al., 1994;

\footnotetext{
* Corresponding author at Applied Ecology Group, Department of Environmental and Geographical Sciences, the Manchester Metropolitan University, Chester St, Manchester M1 5GD, UK. Fax: +44-161247-6318.

E-mail address: s.marsden@mmu.ac.uk (S.J. Marsden).
}

Goerck, 1997) but, in some species, also through direct exploitation (Martuscelli, 1995; Galetti et al., 1997). Altogether, 21 parrot species occur in the region, of which seven are classified as Endangered and two Vulnerable (Collar et al., 1994). The Sooretama/Linhares reserve complex in Espírito Santo state has been identified as a stronghold for lowland parrot species such as blue-chested parakeet (Pyrrhura cruentata) (Forshaw, 1989; Wege and Long, 1995), and research on the status, population sizes, and habitat use of parrots in, and around the reserve has been identified as high priority (Snyder et al., 2000).

We aimed to assess the conservation status of parrots in Sooretama/Linhares, and in forest fragments around the reserve. We also compared the status of parrots in this large reserve complex with that in the small reserve at Porto Seguro, $600 \mathrm{~km}$ away in Bahia state (Fig. 1). Specifically, we aimed to:

1. Estimate population densities and total population sizes of parrots in each area. 


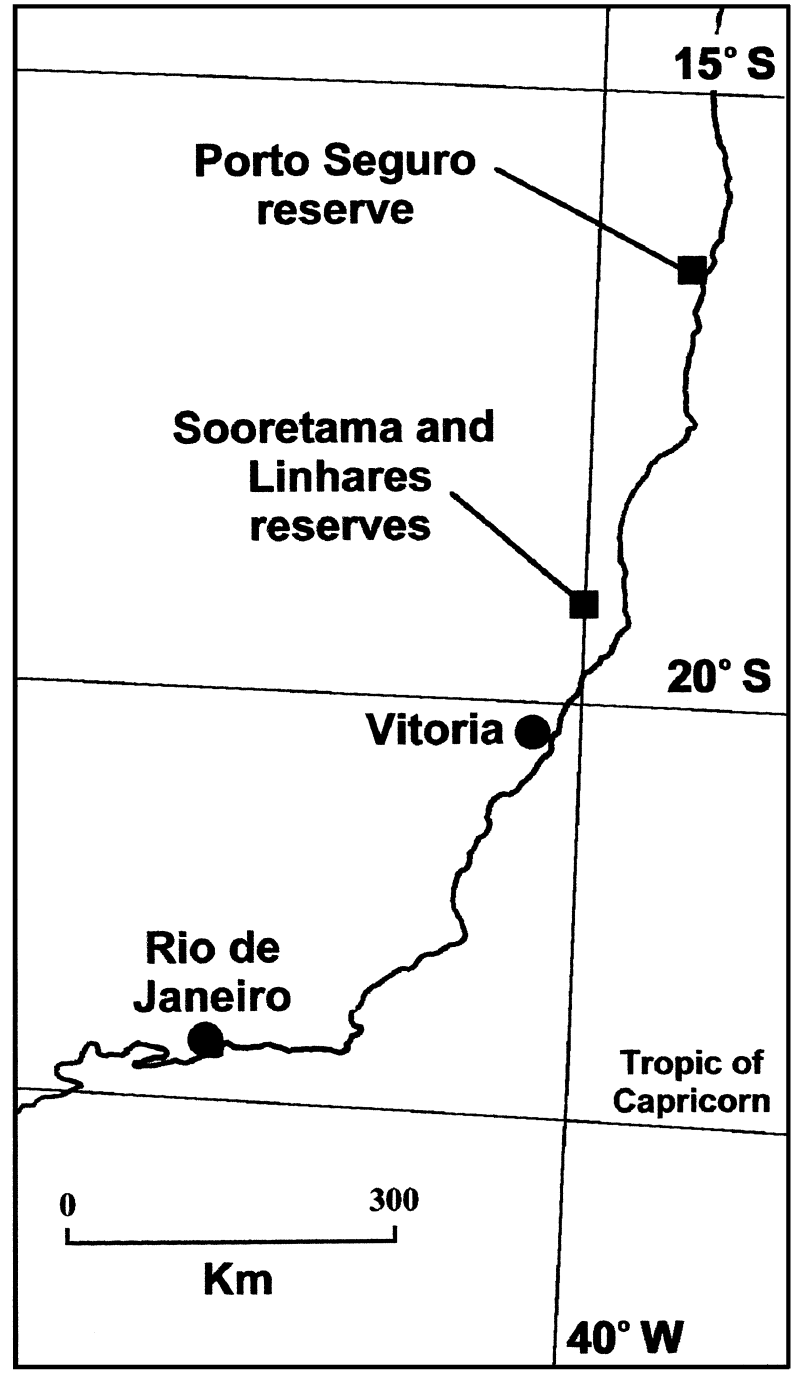

Fig. 1. South-eastern Brazil showing the positions of the Porto Seguro and Sooretama/Linhares reserves.

2. Identify the habitat associations of parrots, to determine the effects of habitat change on individual species.

3. Examine the movements of parrots between Sooretama reserve and surrounding forest fragments to gauge the importance of unprotected areas outside the reserve for parrots.

\section{Methods}

\subsection{Study sites and parrot species}

The Porto Seguro complex in Bahia state $\left(16^{\circ} 27^{\prime} \mathrm{S}\right.$ $39^{\circ} 15^{\prime} \mathrm{W}$ ) comprises 6000 ha of the Florestas Rio Doce SA private Forestry Reserve, which is contiguous with 600 ha of forest at the CEPLAC (Comissão Executiva do Plano da Lavoura Cacaueira) Pau-Brasil Ecological Station (Fig. 2). This isolated forest complex is situated

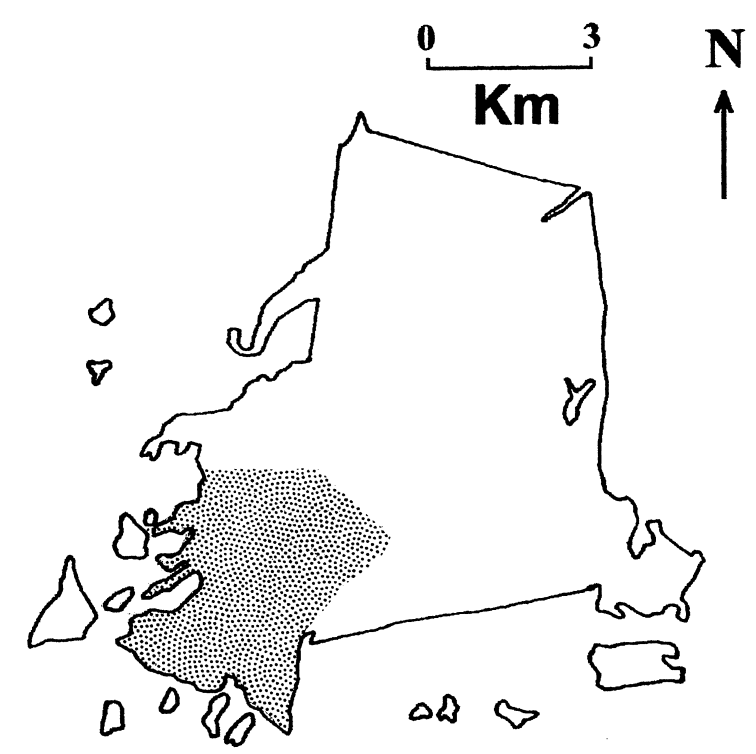

\section{Area of census}

Fig. 2. The Porto Seguro reserves. Areas outside the reserve are dominated by pasture and arable farmland.

close to sea level c. $10 \mathrm{~km}$ inland from the town of Porto Seguro, amidst pasture, coffee plantation, and arable farmland (Wege and Long, 1995). Much of the forest in Florestas Rio Doce SA Reserve has been recently selectively logged, but the CEPLAC Pau-Brasil Reserve, in which most bird surveying was done, has not been logged recently.

The Sooretama/Linhares complex of east-central Espírito Santo state, comprises the 24,250 ha Sooretama Federal Biological Reserve $\left(19^{\circ} 03^{\prime} \mathrm{S} 40^{\circ} 00^{\prime} \mathrm{W}\right)$, which lies adjacent to the 21,800 ha Linhares Forestry Reserve $\left(19^{\circ} 10^{\prime} \mathrm{S}, 39^{\circ} 55^{\prime} \mathrm{W}\right)$, owned by Companhia Vale de Rio Doce (Wege and Long, 1995; Chiarello, 1999). The reserves lie close to sea level, and are composed mostly of 'terra firme' forest up to $40 \mathrm{~m}$ in height, with some 'mussununga' forest containing much smaller trees on sandier soils (Simão et al., 1997). There is a history of logging within the reserves (illegal logging persists in Sooretama) and some areas of forest are secondary growth. Much of the area around the reserve has been deforested, although some private preserves remain. Major land uses in the vicinity of the reserves include pasture, extensive Eucalyptus plantations, arable farmland and coffee plantation. So far, 14 and seven parrot species have been documented as occurring in Sooretama/ Linhares and Porto Seguro, respectively (Table 1).

Parrot surveys were made between 21 July and 16 October 1998 in the Porto Seguro forestry reserve and in the Sooretama/Linhares reserve and in 31 forest fragments between 10 and 150 ha within $7 \mathrm{~km}$ of this latter area (Fig. 3). The survey period corresponds to 
Table 1

Status of parrots known to occur within the study areas and/or recorded during our fieldwork ${ }^{\mathrm{a}}{ }^{\mathrm{b}}$

\begin{tabular}{|c|c|c|c|}
\hline Species & Status & Sooretama/Linhares & Porto Seguro \\
\hline Blue-winged macaw Propyrrhura maracana & Vulnerable & $a, b$ & \\
\hline Peach-fronted parakeet Aratinga aurea & & $a, b$ & \\
\hline White-eyed parakeet Aratinga leucophthalmus & & $\mathrm{b}$ & \\
\hline Blue-chested parakeet Pyrrhura cruentata & Vulnerable & $a, b$ & $a, b$ \\
\hline Maroon-faced parakeet Pyrrhura leucotis & & $\mathrm{a}, \mathrm{b}$ & \\
\hline Blue-winged parrotlet Forpus xanthopterygius & & $a, b$ & $a, b$ \\
\hline Golden-tailed parrotlet Touit surda & Endangered & a & a \\
\hline Plain parakeet Brotogeris tirica & & $a, b$ & $a, b$ \\
\hline Scaly-headed parrot Pionus maximiliani & & $a, b$ & \\
\hline Blue-headed parrot Pionus menstruus & & $\mathrm{a}, \mathrm{b}$ & $a, b$ \\
\hline Orange-winged Amazon Amazona amazonica & & $a, b$ & $\mathrm{~b}$ \\
\hline Mealy Amazon Amazona farinosa & & $a, b$ & a \\
\hline Red-browed Amazon Amazona rhodocorytha & Endangered & $a, b$ & $a, b$ \\
\hline Blue-fronted Amazon Amazona aestiva & & $\mathrm{a}$ & \\
\hline Blue-bellied parrot Triclaria malachitacea & Endangered & $\mathrm{a}, \mathrm{b}$ & \\
\hline
\end{tabular}

${ }^{a}$ Status is the IUCN red list category for that species in the Parrot Action Plan (Snyder et al., 2000).

b a previously recorded (e.g. Parker and Goerck, 1997), b recorded at any time during current study.

the dry, cold season prior to the main breeding season for parrots in the region (Forshaw, 1989; Martuscelli, 1995).

\subsection{Parrot surveys}

Four weeks prior to the census were spent practising bird identification and distance estimation. All parrot surveying was done by a pair of observers (with M.W. always the primary recorder). A variable circular plot method (Reynolds et al., 1980; Jones et al., 1995), tailored for parrot census (Marsden, 1999), was used to calculate density estimates (individuals per $\mathrm{km}^{2}$ ) for parrots inside the reserves and in forest fragments. The distance sampling method used allows for unidentified bird contacts, so long as all birds encountered at and very close to the recorder are identified (Buckland et al., 1993; Marsden, 1998).

In all areas sampled, transects were set up along existing paths of width $<3 \mathrm{~m}$. Census stations were marked out along these transects at intervals of 200 paces $($ c. $200 \mathrm{~m})$. Parrots were counted at each point twice, on different days, points being visited in reverse order on the second visit. Surveys were carried out between 0700 and 1130 hours and only in the absence of rain or heavy mist. Birds were counted at each census station for a period of $10 \mathrm{~min}$. The distance from the recorder to each bird encountered was estimated. The number of individuals in each encounter was recorded, if ascertainable. When approaching a census station any birds that were disturbed (flushed) from the plot these were recorded as being present during the census period. The census period commenced immediately on arrival at the station.

Records of parrots in flight at census stations were omitted from the density calculations because aerial birds violate an assumption of the census method used (Marsden, 1999). For contacts where birds were only heard, the mean group size for visual contacts with that species was substituted for the missing group size

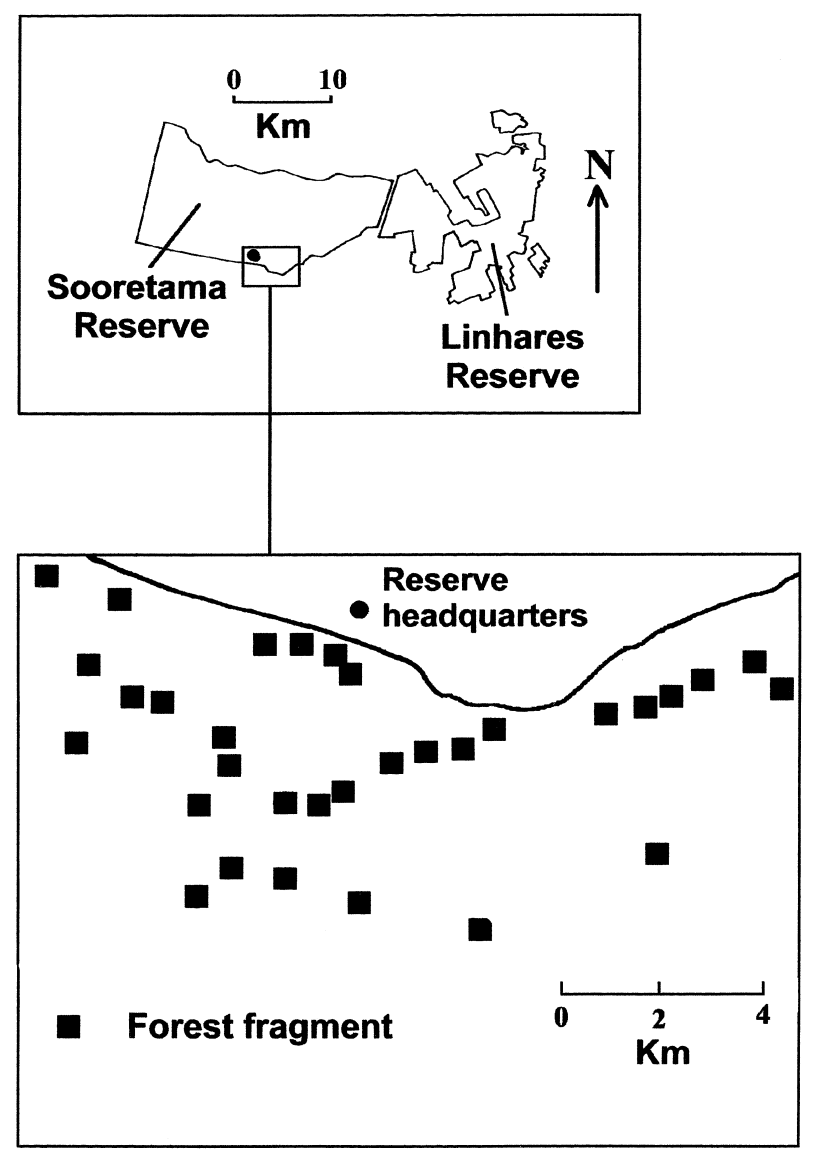

Fig. 3. The Sooretama and Linhares reserves showing the positions of the 31 forest fragments surveyed. 
values. Such contacts need to be included in the calculations because excluding any parrot contact at or close to the recorder will result in underestimation of densities (Marsden, 1999).

\subsection{Habitat recording}

At each census station, the two trees of largest girth within $25 \mathrm{~m}$ of the station's central point were selected, their girths at breast height measured, and their heights estimated using a clinometer. The percentage vegetative cover within $25 \mathrm{~m}$ of the central point, at canopy level, mid-level (10-20 m), and ground levels were estimated to the nearest $10 \%$. The number of palms (Astrocaryum, Schellea and Bactris) of dbh $>0.6 \mathrm{~m}$ within $25 \mathrm{~m}$ of the plot's central point were counted, and the presence or absence of bamboo and Cecropia spp. trees recorded.

\subsection{Study of parrot movements}

On 26 dates between 12 August and 4 October, the flight movements of parrots between the Sooretama reserve and outlying countryside were recorded from the forest edge. Two watches were done each day, one in the morning from 0600 to 0800 and one in the afternoon between 1600 and 1800 (parrots were also watched at other times and from other sites but these data are not considered here). All watches were done by the same recorder (LS) and were undertaken from a point close to the park headquarters along the road bordering the edge of the reserve $\left(19^{\circ} 03.340^{\prime} \mathrm{S} 40^{\circ} 08.039^{\prime} \mathrm{W}\right)$. All parrots flying either into or out of the reserve within a distance of $500 \mathrm{~m}$ either side of the recorder were noted. All Amazons within this range were readily identifiable, but some medium-sized parrots had to be recorded as Pionus sp. and some parakeets as Pyrrhura/Brotogeris. For each parrot group encountered, the time of the encounter was noted along with the species, group size, direction of flight and where birds landed, if this was ascertainable.

\subsection{Data analyses}

Parrot abundance is first expressed as encounter rates (number of groups of a parrot species recorded per 10 point counts). For some species, density estimation was possible using the DISTANCE 3.5 program (Laake et al., 1994). However, for only some species were there sufficient records to calculate density estimates based only on the detection function for that reserve or habitat. In other species, records from both the reserves and the fragments were combined to produce a single detection function, from which specific density estimates were calculated for each reserve and fragments (Laake et al., 1994; Marsden, 1999). Density estimates with their associated standard errors were used to estimate total population sizes in the two reserves, using the areas of the reserves given in Wege and Long (1995).

For each species, a logistic regression was used to identify differences in habitat between the positive stations (those at which the species was recorded on either visit) and negative stations, at which the species was not recorded (Norušis, 1993; Dettmers et al., 1999; Marsden and Fielding, 1999). All variables were entered in the analysis simultaneously. Two analyses were performed for each species, one for all stations together (both reserves plus forest fragments $=440$ points), and one including only points in Sooretama/Linhares (273 points). Analysis was restricted to species recorded at more than 20 points altogether. Six habitat variables were considered in the analyses. Presence/absence of bamboo and Cecropia spp. were entered as categorical data, while the number of palms was entered as a continuous count. The remaining variables (tree sizes and vegetative covers) were simplified to a smaller number of orthogonal factors using principal component analysis (Norušis, 1993).

Data on the movements of parrots are expressed as the mean number of bird groups and individuals per hour ( \pm S.D.) flying to and from the reserve during the morning and afternoon. For each species and each period, the numbers entering the reserve were compared to the numbers leaving the reserve using Wilcoxon signed-rank tests.

\section{Results}

\subsection{Population parameters}

In total, 134 counts were made at 67 points at Porto Seguro, 546 counts were made at 273 points at Sooretama/Linhares, and 200 counts at 100 points in forest fragments. These figures equate to one point count per 49 ha at Porto Seguro, and one per 84 ha at Sooretama/ Linhares. All but two of the 14 parrot species previously recorded from either reserve were recorded during the fieldwork. Those exceptions were golden-tailed parrotlet (Touit surda) and blue-fronted Amazon (Amazona aestiva). One additional species, white-eyed parakeet (Aratinga leucophthalmus), was recorded occasionally in forest fragments and at the forest edge at Sooretama but is not previously listed for that reserve. Blue-bellied parrot (Triclaria malachitacea) was recorded only once at the forest edge in Sooretama, and blue-winged parrotlet (Forpus xanthopterygius) was recorded only once at Porto Seguro (neither was recorded during formal surveys). In total, 13 species were recorded in Sooretama/Linhares, eight in fragments around Sooretama, and only six species in Porto Seguro. Encounter rates were generally higher in Sooretama than in fragments or particularly in Porto Seguro (Table 2). 
Table 2

Parrot encounter rates (no. groups encountered per 10 point counts) and total numbers of groups encountered (figures in parentheses) in Porto Seguro and Sooretama/Linhares reserves, and in forest fragments around Sooretama ${ }^{a}$

\begin{tabular}{llll}
\hline & Porto Seguro & Sooretama & Fragments \\
\cline { 2 - 4 } & $(n=134)$ & $(n=546)$ & $(n=200)$ \\
\hline Propyrrhura maracana & 0 & $0.11(6)$ & $0.05(1)$ \\
Aratinga aurea & 0 & $0.02(1)$ & 0 \\
Aratinga leucophthalmus & 0 & 0 & $0.05(1)$ \\
Pyrrhura cruentata & $0.07(1)$ & $0.49(27)$ & 0 \\
Pyrrhura leucotis & 0 & $0.44(24)$ & 0 \\
Forpus xanthopterygius & 0 & $0.02(1)$ & $0.1(2)$ \\
Brotogeris tirica & $0.37(5)$ & $0.55(30)$ & 0 \\
Pionus maximiliani & 0 & 0 & $0.05(1)$ \\
Pionus menstruus & $0.15(2)$ & $0.13(7)$ & $0.05(1)$ \\
Amazona amazonica & $0.37(5)$ & $0.37(20)$ & $0.25(5)$ \\
Amazona farinosa & 0 & $0.11(6)$ & $0.1(2)$ \\
Amazona rhodocorytha & $0.15(2)$ & $0.60(33)$ & $0.45(9)$ \\
\hline
\end{tabular}

a $n=$ number of point counts (including repeats).

In all species for which density estimation was possible, densities in Sooretama were higher than at Porto Seguro or in the forest fragments (Table 3). The three parakeets (Pyrrhura and Brotogeris) had population estimates within Sooretama in excess of 10,000 , while other parrots had estimates in excess of 1000 individuals. In contrast, only one species ( $B$. tirica) had a population estimate in excess of 500 in Porto Seguro.

\subsection{Habitat associations}

Principal component analysis extracted three factors, which together accounted for $84 \%$ of variation in the five habitat readings. Factor 1 (eigenvalue $=1.9$ ) was strongly positively correlated with average tree heights $(r=+0.91)$ and tree girths $(r=+0.91)$, while factor 2 (eigenvalue $=1.2$ ) was positively correlated with ground cover $(r=+0.90)$ and negatively correlated with canopy cover $(r=-0.67)$. The third factor (eigenvalue $=1.1$ ) was composed almost entirely of differences in mid-level vegetation cover $(r=+0.95)$.

There were sufficient records of five parrot species to examine habitat associations using logistic regression
(Table 4). For all areas, three species including two Amazona were associated with high scores on factor 1 (associated with large trees), while Pyrrhura cruentata was associated with areas containing Cecropia and full vegetation cover at canopy and mid-level (low scores on factor 2 and high scores on factor 3). Considering only Sooretama/Linhares, Cecropia was again important for $P$. cruentata suggesting it is a bird of regenerating forest. The two Amazons were strongly linked to large trees, but also with relatively open canopies.

\subsection{Parrot movements}

Parrots made more frequent flights into and out of the Sooretama reserve in the mornings than the afternoons (Table 5). There was a significant net flow of P. maracana out of the reserve in the mornings and back in again in the afternoon. Two Amazon species moved in the opposite direction, with many individuals flying into the reserve, presumably having roosted outside the reserve. Mean numbers of Pionus recorded flying in and out of the reserve were high, given that the two species were not common in the reserve. B. tirica did tend to leave the reserve in the mornings, but there was very little movement of parakeets between the reserve and the surrounding areas — particularly given the high population densities of all three species.

Of 65 parrot groups seen to land outside the reserve, $72 \%$ landed in forest fragments, $22 \%$ in orange groves, and $6 \%$ in isolated fruit trees. Excluding P. maracana which landed in orange groves 12 of 22 times, the remaining species landed in forest fragments on 39 of 43 occasions.

\section{Discussion}

Brazil's Atlantic forest has been described as one of the world's most threatened ecosystems (Myers, 1988). Forest loss continues, as does degradation of remaining forest through logging. Remnant forest patches are increasingly isolated, and outside reserves there may be an increase in land uses, such as sugar cane, that are of

Table 3

Density estimates \pm coefficients of variation (D.E. \pm C.V.) and population estimates (P.E. \pm S.E.) for parrots in Porto Seguro and Sooretama/Linhares reserves, and in forest fragments around Sooretama

\begin{tabular}{|c|c|c|c|c|c|}
\hline & \multicolumn{2}{|c|}{ Porto Segure $\left(66.0 \mathrm{~km}^{2}\right)$} & \multicolumn{2}{|c|}{ Sooretama/Linhares $\left(461 \mathrm{~km}^{2}\right)$} & \multirow{2}{*}{$\frac{\text { Fragments }}{\text { D.E. } \pm \text { C.V }}$} \\
\hline & D.E. \pm C.V. & P.E. \pm S.E. & D.E. \pm C.V. & P.E. \pm S.E. & \\
\hline Pyrrhura cruentata & $4.8 \pm 100$ & $317 \pm 317$ & $41 \pm 22$ & $19,000 \pm 4180$ & \\
\hline Pyrrhura leucotis & & & $42 \pm 25$ & $19,300 \pm 4840$ & \\
\hline Brotogeris tirica & $18 \pm 51$ & $1180 \pm 602$ & $28 \pm 25$ & $12,800 \pm 3210$ & \\
\hline Pionus menstruus & $1.0 \pm 100$ & $66 \pm 66$ & $2.3 \pm 47$ & $1060 \pm 498$ & $1.3 \pm 100$ \\
\hline Amazona amazonica & $1.5 \pm 62$ & $100 \pm 62$ & $3.1 \pm 25$ & $1430 \pm 357$ & $2.2 \pm 67$ \\
\hline Amazona rhodocorytha & $3.6 \pm 73$ & $238 \pm 174$ & $13 \pm 28$ & $5990 \pm 1680$ & $7.8 \pm 43$ \\
\hline
\end{tabular}


Table 4

Results of logistic regression for parrots in all areas/habitats, and, in parentheses, in Sooretama/Linhares reserve only ${ }^{\mathrm{a}}$

\begin{tabular}{|c|c|c|c|c|}
\hline & P. cruentata & B. tirica & A. rhodocorytha & A. amazonica \\
\hline Positive stations & $25(24)$ & $33(27)$ & $37(27)$ & $26(19)$ \\
\hline \multicolumn{5}{|l|}{ Habitat variables } \\
\hline Factor 1 & & $+*$ & $+*(+* * *)$ & $+*(+* * *)$ \\
\hline Factor 2 & $-*$ & & $(+* *)$ & $(+*)$ \\
\hline Factor 3 & $+*$ & & $(-*)$ & $(+*)$ \\
\hline \multicolumn{5}{|l|}{ Palms } \\
\hline \multicolumn{5}{|l|}{ Bamboo } \\
\hline Cecropia & $+*(+*)$ & & & \\
\hline
\end{tabular}

a A plus sign denotes that high values of that variable are associated with species presence (a minus sign mean high values associated with species absence). $* P<0.05, * * P<0.005, * * * P<0.0005$.

Table 5

Mean \pm S.D. numbers of individual parrots recorded flying out of, and into the Sooretama reserve during 2 -h periods of the mornings and afternoons $^{\mathrm{a}, \mathrm{b}}$

\begin{tabular}{|c|c|c|c|c|}
\hline & \multicolumn{2}{|c|}{ Mornings (06h00-08h00) } & \multicolumn{2}{|c|}{ Afternoons (16h00-18h00) } \\
\hline & Flying out & Flying in & Flying out & Flying in \\
\hline P. maracana & $5.1 \pm 6.4$ & $1.9 \pm 3.9^{*}$ & $0.11 \pm 0.60$ & $3.4 \pm 6.2 *$ \\
\hline P. cruentata & $0.93 \pm 2.9$ & 0.0 & 0.0 & 0.0 \\
\hline P. leucotis & $0.18 \pm 0.94$ & $0.14 \pm 0.76$ & 0.0 & 0.0 \\
\hline B. tirica & $5.5 \pm 7.3$ & $2.6 \pm 4.8^{*}$ & 0.0 & $0.07 \pm 0.38$ \\
\hline Pyrrhura/Brotogeris & $0.50 \pm 2.5$ & $3.3 \pm 11$ & 0.0 & $0.08 \pm 0.39$ \\
\hline P. maximiliani & $0.92 \pm 2.7$ & $0.69 \pm 2.7$ & $0.08 \pm 0.39$ & $0.31 \pm 1.6$ \\
\hline P. menstruus & $0.27 \pm 0.96$ & $0.27 \pm 1.0$ & 0.0 & 0.0 \\
\hline Pionus sp & $3.1 \pm 5.3$ & $3.0 \pm 4.9$ & $0.07 \pm 0.39$ & 0.0 \\
\hline A. amazonica & $1.7 \pm 1.7$ & $4.6 \pm 4.8^{* *}$ & $2.4 \pm 4.1$ & $0.21 \pm 1.1^{* *}$ \\
\hline A. farinosa & $0.23 \pm 0.65$ & $0.54 \pm 1.3$ & $0.08 \pm 0.39$ & $0.08 \pm 0.39$ \\
\hline A. rhodocorytha & $1.5 \pm 2.2$ & $8.9 \pm 11 * *$ & $0.81 \pm 1.9$ & $0.48 \pm 0.85$ \\
\hline
\end{tabular}

a Differences in mean numbers flying in and out were tested using Wilcoxon signed-ranks tests. ${ }^{*} P<0.05, * * P<0.005$.

b In all cases, $n=26$ (two-hour periods).

little or no use to parrots. Of 21 parrot species occurring in lowland Atlantic forest, nine are threatened with extinction (Collar et al., 1994).

While areas of the forest are under protection through a system of federal and state reserves, privately-owned reserves, and privately-owned forest patches, most reserves are small, and viable populations of very rare species may be preserved in only a few large reserves. There are only two areas larger than Sooretama/Linhares, and only six larger than Porto Seguro, that are actually known to hold populations of either the Vulnerable $P$. cruentata or the Endangered A. rhodocorytha, (Table 6; data from Wege and Long, 1995). Furthermore, the status of these two species in the two largest areas is far from clear. P. cruentata has been recorded from one section of the Chapada Diamantina National Park in the $1980 \mathrm{~s}$, while there is a single record of four A. rhodocorytha from Serra da Bocaina in 1994 (Wege and Long, 1995). Clearly, for some parrot species, there are few if any populations bigger than those reported in this paper.
Two parrot species listed as occurring in Porto Seguro and two listed for Sooretama were not found during our surveys. Of most concern was the lack of records from both reserves of the 'Endangered' golden-tailed parrotlet (Touit surda) which, although known from a number of locations, may occur in most areas at very low population densities (Forshaw, 1989; Wege and Long, 1995). In general, however, we found or expected significant populations of most species in the large reserve complex of Sooretama/Linhares. For example, an aggregation of 84 blue-winged macaws ( $P$. maracana) (listed as Vulnerable) was recorded at Sooretama, whereas, previously, just one or two pairs have been reported from the reserve. The importance of Sooretama as a stronghold for parrots and other threatened bird species, such as red-billed curassow (Crax blumenbachii), cannot be overstated, and such reserves must form the cornerstone of efforts to preserve the region's threatened endemics in the long term.

In contrast, some parrot species were absent from Porto Seguro and populations of almost all species were 
Table 6

Sizes of key areas known to hold populations of P. cruentata and/or A. rhodocorytha (from Wege and Long, 1995) ${ }^{\mathrm{a}}$

\begin{tabular}{lccc}
\hline Key area and status & Size (ha) & P. cruentata & A. rhodocorytha \\
\hline Chapada Diamantina (National Park) & 152,000 & + & \\
Serra da Bocaína (National Park) & 100,000 & + & + \\
Sooretama/Linhares (Federal/Private Reserve) & 46,050 & + & + \\
Rio Doce (State Park) & 35,973 & + & + \\
Monte Pascoal (National Park) & 22,500 & + & + \\
Desengano (State Park) & 22,500 & + & + \\
Porto Seguro (CEPLAC/Private Reserve) & 6600 & + & + \\
Nova Lombardia (Federal Reserve) & 4492 & + \\
Córrego doVeado (Federal Reserve) & 2392 & \\
Córrego Grande (Federal Reserve) & 1504 & \\
Ibitipoca (State park) & 1488 & & + \\
Caratinga (Private Reserve) & 880 & + \\
Barrolândia (Private Reserve) & 710 & + \\
\hline
\end{tabular}

a A plus sign indicates the parrot species has been recorded within, or $+*$ nearby the reserve.

low. It is not known why population densities of parrots were low in this reserve, but habitat alteration, direct exploitation, and problems of small population size may all have contributed to species rarity. What does seem clear is that this is a situation mirrored in other forest remnants in the region with fewer parrot species and lower numbers of parrots being recorded in the small reserves (e.g. Wege and Long, 1995). It seems likely that such small populations of parrots as were found in Porto Seguro may be open to problems of viability in the long-term (Franklin, 1980; Lynch and Lande, 1998).

Indications are that hunting pressure in the reserves was high despite continuing patrols at Sooretama. At Porto Seguro, several hunting 'perches' were sited in trees beside the trails, while hunting trails parrot trappers' ladders, and hunters themselves were encountered at Sooretama and in nearby forest fragments. While it is not known what precise effect illegal trapping is having on parrots around either reserve, trapping, particularly of young from nests, is seen as a major threat to some species elsewhere (Collar and Juniper, 1992; Martuscelli, 1995).

A more general threat in both areas is habitat alteration. Much of the forest surveyed had been heavily logged, and habitat alteration, both due to encroachment at the reserve borders and the poaching of large trees for timber from inside the reserves was seen to remain a problem during our survey. This is not to say that all forest alterations are necessarily bad for all parrot species: we found $P$. cruentata to be associated with areas containing high proportions of the pioneer tree family Cecropiaceae, the fruits/seeds of which are a chosen food of Pyrrhura and Brotogeris (Pizo et al., 1995; Simão et al., 1997). However, several species, particularly Amazona were strongly associated with 'big-tree' forest and were absent from large areas of Sooretama. These, and probably other species, may continue to be affected by extraction of large trees, particularly through illegal logging. In addition to logging, Sooretama has a history of forest fires, and during our fieldwork a large forest fire burnt c. 4000 ha of forest (c. $20 \%$ of the Sooretama reserve area). Little is known of the full effects of such fires on parrot populations or ecology, and given the importance of fire in and around the region's forests, research on this aspect of parrot ecology is needed.

Because Sooretama is so important as a reserve for parrots, it may be that areas around this reserve should be identified as having higher priority in terms of management for threatened species than areas away from conservation strongholds. Our study shows that even small forest fragments can be of considerable value to some parrot species. However, whether such fragments are used by species may depend in part on their proximity to large tracts of forest, and the ability of parrots to travel between areas. We found Amazona, Pionus and the macaw $P$. maracana to fly regularly between reserve and forest fragments, and such flights are well known elsewhere (Forshaw, 1989; Martuscelli, 1995). Other species, notably two Pyrrhura and one Brotogeris parakeets were not recorded in forest fragments during the survey, and were rarely observed leaving the reserve. These species generally tolerate disturbed forests (Ridgely, 1981; Forshaw, 1989), suggesting that it may be unwillingness to pass between reserve and forest fragments, and not unsuitability of (generally disturbed) forest in the fragments, that stopped the parakeets from using patches outside the reserve.

Little has been documented as to the usage of agricultural and other man-altered land uses by Atlantic forest parrots. Some habitats are certainly of little use to parrots, and these include Eucalyptus plantations, pasture, and sugar cane and other arable crops. Other habitats outside reserves are more important and these include forest fragments and 'Cabrucagem' shade cocoa plantations. Some of the more traditional cocoa growing regimes have been identified as useful for nature conservation (Johns, 1998), and may be well utilised by parrots such as P. cruentata (Forshaw, 1989). 
It may be that the preservation and regeneration of forest fragments around certain stronghold reserves may yield high returns for species conservation at comparatively low cost. It is also likely that considerations of the shape and connectiveness of such patches, and/or the promotion of more sympathetic land uses between forested areas, will extend the benefit offered to a wider range of species (Saunders et al., 1991; Lamb et al., 1997).

For such conservation management regimes to be properly proposed and justified, more needs to be known about the ecology of wildlife in and around the large reserves. For the formulation of a successful parrot conservation strategy in the region, the following are seen as priorities for research:

1. Identification of a critical set of parrot strongholds, and the assessment of population sizes within these areas, as a basis for long-term monitoring.

2. Research into the precise usage of strongholds by key parrot species, in terms of how their requirements for breeding, feeding and roosting can be fulfilled by forest within reserves and in surrounding habitats.

\section{Acknowledgements}

The project was funded by Blackpool Zoo, and we thank Iain Valentine for his help in initiating the project. Mauro Galetti hosted the project at Universidade Estudual Paulista and was extremely supportive throughout. Permission to conduct research, logistical help and accommodation was kindly provided by Sr. Gilberto Gerhardt of IBAMA- Espírito Santo, and Sr. Renato de Jesus of Linhares CVRD. Mauro Galetti and Rory Putman kindly commented on the manuscript.

\section{References}

Buckland, S.T., Anderson, D.R., Burnham, K.P., Laake, J.L., 1993. Distance Sampling: Estimating Abundance of Biological Populations. Chapman and Hall, London.

Chiarello, A.G., 1999. Effects of fragmentation of the Atlantic forest on mammal communities in south-eastern Brazil. Biological Conservation $89,71-82$.

Collar, N.J., Juniper, A.T., 1992. Dimensions and causes of the parrot conservation crisis. In: Beissinger, S.R., Snyder, N.F.R. (Eds.), New World Parrots in Crisis: Solutions From Conservation Biology. Smithsonian Institution Press, Washington DC, pp. 1-24.

Collar, N.J., Crosby, M.J., Stattersfield, A.J. 1994. Birds to Watch 2: The World List of Threatened Birds. Birdlife Conservation Series No. 4. Cambridge, UK.

Dettmers, R., Buehler, D.A., Bartlett, J.G., Klaus, N.A., 1999. Influence of point count length and repeated visits on habitat model performance. Journal of Wildlife Management 63, 815-823.

Fonseca, G.A.B., 1985. The vanishing Brazilian Atlantic forest. Biological Conservation 34, 17-34.

Forshaw, J.M., 1989. Parrots of the World, 3rd Edition. Landsdowne Editions, Melbourne.
Franklin, I.R., 1980. Evolutionary change in small populations. In: Soulé, M.E., Wilcox, B.A. (Eds.), Conservation Biology: An Evolutionary-ecological Perspective. Sinauer, Sunderland, pp. 135-150.

Galetti, M., Martuscelli, P., Olmos, F., Aleixo, A., 1997. Ecology and conservation of the Jacutinga Pipile jacutinga in the Atlantic Forest of Brazil. Biological Conservation 82, 31-39.

Goerck, J.M., 1997. Patterns of rarity in the birds of the Atlantic Forest of Brazil. Conservation Biology 11, 112-118.

Johns, N.D., 1998. Conservation in Brazil's chocolate forest: the unlikely persistence of the traditional cocoa agroecosystem. Environmental Conservation 23, 31-47.

Jones, M.J., Linsley, M.D., Marsden, S.J., 1995. The status, population sizes and habitat associations of the restricted-range bird species of Sumba, Indonesia. Bird Conservation International 5, 21-52.

Laake, J.L., Buckland, S.T., Anderson, D.R., Burnham, K.P., 1994. DISTANCE user's guide, V2.1. Colorado Co-operative Fish and Wildlife Research Unit, Colorado State University, Fort Collins, CO.

Lamb, D., Parrotta, J., Keenan, R., Tucker, N., 1997. Rejoining habitat remnants: restoring degraded rainforest lands. In: Laurance, W.F., Bierregaard Jr., R.O. (Eds.), Tropical Forest Remnants: Ecology, Management, and Conservation of Fragmented Communities. The University of Chicago Press, Chicago, pp. 366-387.

Lynch, M., Lande, R., 1998. The critical effective size for a genetically secure population. Animal Conservation 1, 70-72.

Marsden, S.J., 1998. Changes in bird abundance following selective logging on Seram, Indonesia. Conservation Biology 12, 605-611.

Marsden, S.J., 1999. Estimation of parrot and hornbill densities using a point count distance sampling method. Ibis 141, 377-390.

Marsden, S.J., Fielding, A.H., 1999. Habitat associations of parrots on the Wallacean islands of Buru, Seram and Sumba. Journal of Biogeography 26, 439-446.

Martuscelli, P., 1995. Ecology and conservation of the Red-tailed Amazon Amazona brasiliensis in south-eastern Brazil. Bird Conservation International 5, 405-420.

Myers, N., 1988. Threatened biotas: "hotspots" in tropical forests. Environmentalist 8, 1-20.

Norušis, M.J., 1993. SPSS for Windows Professional Statistics 6.1., SPSS Inc, Chicago.

Parker III, T.A., Goerck, J.M., 1997. The importance of national parks and biological reserves to bird conservation in the Atlantic forest region of Brazil. Ornithological Monographs 48, 527-541.

Pizo, M.A., Simão, I., Galetti, M., 1995. Diet and flock size of sympatric parrots in the Atlantic forest of Brazil. Ornithología Neotropical 6, 87-95.

Ranta, P., Blom, T., Niemela, J., Joensuu, E., Siitonen, M., 1998. The fragmented Atlantic rain forest of Brazil: size, shape and distribution of forest fragments. Biodiversity and Conservation 7, 385403.

Reynolds, R.T, Scott, J.M., Nussbaum, R.A., 1980. A variable circular plot method for estimating bird numbers. Condor 82, 309313.

Ridgely, R.S., 1980. The current distribution and status of mainland neotropical parrots. In: Pasquier, R.F. (Ed.), Conservation of New World Parrots. ICBP Technical Publication No. 1. Cambridge, UK, pp. 233-284.

Saunders, D.A., Hobbs, R.J., Margules, C.R., 1991. Biological Consequences of Ecosystem Fragmentation: A Review. Conservation Biology 5, 19-32.

Sick, H., 1993. Birds in Brazil: A Natural History. Princeton University Press, Princeton, NJ.

Simão, I., Maës dos Santos, F.A., Aurelio Pizo, M., 1997. Vertical stratification and diet of psittacids in a tropical lowland forest of Brazil. Ararajuba 5, 169-174.

Snyder, N., McGowan, P., Gilardi, J., Grajal, A., (Eds.), 2000. Parrots. Status Survey and Conservation Action Plan. IUCN/SSC, Gland, Switzerland. 
Viana, V.M., Tabanez, A.A.J., Batista, J.L.F., 1997. Dynamics and Restoration of Forest Fragments in the Brazilian Atlantic Moist Forest. In: Laurance, W.F., Bierregaard Jr, R.O. (Eds.), Tropical Forest Remnants: Ecology, Management, and Conservation of
Fragmented Communities. The University of Chicago Press, Chicago, pp. 351-365.

Wege, D.C., Long, A.J., 1995. Key areas for threatened birds in the neotropics. Birdlife Conservation Series, No 5. Cambridge, UK. 